\title{
Marital Histories and Economic Well-Being
}

\author{
Julie Zissimopoulos \\ RAND \\ and \\ Benjamin Karney \\ University of California Los Angeles \\ and \\ Amy Rauer \\ Auburn University
}

Prepared for the $10^{\text {th }}$ Annual Joint Conference of the Retirement Research Consortium "Creating a Secure Retirement System"

August 7-8, 2008

Washington, D.C.

The research reported herein was pursuant to a grant from the U.S. Social Security Administration (SSA) funded as part of the Retirement Research Consortium (RRC). The findings and conclusions expressed are solely those of the authors and do not represent the views of SSA, any agency of the Federal Government or the RRC. We thank Joanna Carroll for her excellent programming assistance. 


\section{Introduction}

Studies have documented substantial differences in household wealth near retirement even among households with similar lifetime earnings (Smith 1995, Gustman and Juster 1996, Venti and Wise 1996, 2000, Zissimopoulos and Hurd 2003). Common explanations for these differences include substitution of Social Security wealth for private wealth (Hubbard, Skinner, Zeldes 1995) differences in rate of time preference (Dynan 1993) and unexpected outcomes in earnings and expenses (Browning and Lusardi 1996). A much less explored explanation is the effect of marriage events even though the higher wealth of married households compared to unmarried (never, divorced or widowed) is well documented. There are several theoretical reasons for this empirical fact: economies of scales in consumption for married couples suggest more consumption with lower expenditures for married couples compared to singles, the loss of income and occurrence of unexpected expenses as a result of divorce or widowhood, and the production of health benefits within marriage leading to lower mortality risk and a need to accumulated wealth to ensure one does not outlive resources in retirement. On the other hand, if marriage acts as income insurance against unexpected events such as job loss, then married couples, all else equal, should hold less wealth than singles.

Although the variation in economic status by a household's current marital status is well documented (Smith 1988) the types of marriage events, when they occurred in the lifecycle and how they affect wealth is not well understood. Indeed, studies of consumption and savings of middle-aged and older individuals often exclude these "nonstandard' households or consider only current marital status (Gustman and Juster 1996). Family composition has changed dramatically over the past 25 years. Divorce rates rapidly increased from the late 1960's through the 1980's and remarriage rates declined. Understanding the impact of marriage, remarriage, divorce, widowhood and its timing on savings and wealth accumulation over the lifecycle will assist us in understanding the economic security of individuals and families in retirement, those entering retirement and has important implications for retirement savings incentives, public income support programs and national savings rates. This paper sheds light on the relationship between a lifetime of relationship events and wealth near retirement through the following analyses. 
First, using the Health and Retirement Study's detailed information on multiple birth cohorts' marital histories and dates of events, we categorize marital status for respondents by type (divorce, widowhood, remarriage after widowing, remarriage after divorce, continuous marriage, never married) by number of events (e.g. 1 or 2 divorces), and timing (e.g. age at first divorce) and duration of marriages.

Second, we describe the relationship between marriage and wealth for the HRS, War Babies and Early Baby Boomer birth cohorts using bivariate methods. The inclusion of not only marriage types based on current status and previous marital shocks but also the timing of those shocks and duration in marriage increases our understanding of the relationship between wealth and marriage. One way in which duration in a particular state would matter is if there are returns to scale that produce higher levels of consumption in the marriage state. The example of housing, where two people may be able to live as cheaply as one may reduce expenditures and increase savings while married.

Third, we model log wealth as a function of marital categories that take into account current status and past events for men and women controlling for many permanent and transitory attributes of the individual and household that a lifecycle model of savings predicts to affect wealth and that may vary by marriage state. Changes in marital status will alter permanent income, and it is also the case that low-income families are more likely to divorce or experience widowhood than high-income families. We address this type of selection by controlling for the lifetime earnings of individuals as well as current income and then interpret the effect of marital histories on wealth as independent of the effect of earnings and associated selection effects. The model includes demographic characteristics and many other rich controls for likely sources of heterogeneity correlated with marriage such as mortality risk, risk aversion and time rate of preference. The paper proceeds with a background section followed by methods, results and a final section concludes.

\section{Background.}

The standard model for analyzing saving decisions is the life-cycle model (LCM) of consumption (Modigliani and Brumberg, 1954). According to this model individuals 
and households choose a consumption path that will maximize lifetime utility. An important prediction is that households will accumulate savings during the working life, and spend some of the savings to finance consumption following retirement. Although the exact level of asset accumulation will depend on utility function parameters and the interest rate, a useful illustrative case is when the parameters are such that the consumption path is flat as a function of age. Then, in the absence of social programs such as Social Security and other forms of saving such as pensions, and holding the retirement age constant, an individual will save a fixed fraction of lifetime earnings. The empirical literature however, finds that the savings of households with similar income levels can be very different. For example, in the Health and Retirement Study, median non-housing wealth among those with household income of \$25-\$50 thousand was \$34 thousand yet, the 25 th percentile was just $\$ 9.5$ thousand and the 10 th percentile just $\$ 1.2$ thousand (Gustman and Juster, 1996). Households farther up in the income distribution with little private saving may have to reduce consumption sharply during retirement, which is not consistent with the implications of the main theoretical model for saving behavior, the life cycle model of consumption. Common explanations for these differences include substitution of Social Security wealth for private wealth (Hubbard, Skinner, Zeldes 1996) differences in rate of time preference (Dynan 1993) and unexpected outcomes in earnings and expenses (Browning and Lusardi 1996). A much less explored explanation is marriage.

Several hypotheses have been offered for why marriage affects wealth accumulation. An important implication of economic models of savings with no uncertainty (or agents maximize expected utility) and perfect capital markets is that consumption is determined by permanent income. This implies that an unexpected decrease in permanent income would result in lower consumption. Allowing for imperfect capital markets and foresight however, implies an independent role for current income. In terms of changes in marital status, a divorce accompanied by income loss may lead to dissaving rather than a reduction consumption particularly if it is seen as temporary. Married couples may consume many goods and services jointly (e.g. entertainment, housing) for the same cost as a single person. These economies of scale may translate into additional wealth or additional consumption. A marriage interruption 
such as a divorce or widow may involve unexpected expenses. Insurance against future shocks (job loss, health shock) is a motivation for savings (Mincer 1978). Marriage reduces risk associated with fluctuations in income and thus may lower precautionary savings against income shocks or other shocks. Being married is associated with better health throughout the lifespan (Coombs, 1991; Pienta, Hayward, \& Jenkins, 2000), significantly greater longevity (Gove, 1973; House, Landis, \& Umberson, 1988; Lillard and Waite, 1995) thus married couples will save more to protect against outliving their resources. Finally, complex marital histories may complicate financial planning. Married households with similar lifetime earnings may have different wealth levels near retirement if one household was continuously married facilitating the process of planning for retirement while the other household was a remarriage with several marriage transitions over the life-course. Financial literacy may also vary by marital status. For example, if one spouse of the couple specializes in acquiring financial knowledge then upon divorce, the spouse who did not specialize will enter the not married state without this knowledge.

On the other hand, it may be the case that individuals that marry (or remarry) are different than individuals who never marry (or remarry) in terms of ability and earnings, risk aversion, time rate of preference, number of children and access to pension wealth. With regards to children, married couples with children, compared to never married individuals without children, may choose to accumulate wealth in order to leave a bequest to children. Alternatively they may give to adult children while they are alive to ease liquidity constraints (for example for the purchase of a house or education) thereby lowering the wealth available for consumption during retirement. More generally, expenditure on child-related commodities will increase with the number of children and the allocation of time to the labor market may decrease. With regards to earnings, a substantial literature offers various ways that marriage may impact male earnings. Marriage could motivate men to work harder (Becker, 1981), marriage might allow men to specialize in market work (Korenman and Neumark. 1991), or employers could favor married men over unmarried men (Hill, 1979). Alternatively, it could be that men with strong labor market potential make more desirable marriage partners than men with weak labor market potential. In an effort to rule out this selection hypothesis, researchers have 
employed fixed-effect models and generally find a positive effect of marriage or no effect of marriage on male wages (Korenman and Neumark, 1991; Lundberg and Rose, 2002; Loughran and Zissimopoulos, 2007). Considerably less attention has been paid to the effect of marriage on women's earnings because of the strong correlation of marriage and childbearing (one exception is Loughran and Zissimopoulos, 2007). While income is a critical measure of well being, wealth is an important complementary measure and arguably the most important measure for older individuals because it represents resources available for consumption in retirement. Far less is empirically understood about the effect of marriage on wealth although theory suggests it is likely to be important.

Two studies using the HRS and addressing the relationship between wealth and marriage moving beyond an analysis of comparing currently married to unmarried individuals are Wilmoth and Koso (2002) and Lupton and Smith (2000). Both studies confirm earlier findings that married adults have higher wealth than unmarried adults (Gustman \& Juster, 1996; Smith, 1988; Seigel, 1993) although neither study controls for permanent income and other measures likely to be correlated with marital status and wealth such as risk aversion and mortality risk. Wilmoth and Koso (2002) expand the range of marital statuses being studied by looking to marital history to classify remarriages separately from first marriages and find that remarriage appeared to partially offset the detrimental effects of a marital disruption. Lupton and Smith (2000) do not consider remarriage separate from continuous marriage but do examine length of marriage using the HRS and Panel Study of Income Dynamics and find a positive relationship between time spent married and wealth levels.

In sum, there are many pathways through which marriage events may affect wealth. Although empirical findings on marital history, timing of marriage events and duration in marriage are somewhat limited in their scope, the strength of the relationship between marriage and wealth suggests its importance as an area for further study.

\section{Methods}

Our data are from the Health and Retirement Study (HRS). The HRS is a biennial panel with emphasis on retirement behavior and how it is affected by health status, economic status and work incentives. The HRS has a complete inventory of assets and 
income, and these data appear to be of very high quality due to innovative survey techniques. At baseline in 1992 the HRS had 12,652 respondents and was nationally representative of individuals born in 1931-1941 and their spouses except for oversamples of blacks, Hispanics and Floridians. This project uses data from survey wave 1992 for the HRS birth cohort (1931-1941), 1998 for the War Babies birth cohort (1942 1947) and 2004 for the Early Baby Boom birth cohort (1948-1953). These cohorts are especially relevant to understanding the effects of marital history on health as they have experienced substantially higher divorce rates than previous cohorts and they are more likely to be entering older adulthood with a diverse history of marital experiences (Cherlin, 1992). We exclude two birth cohorts, Children of the Depression Era birth cohort (1924 - 1930) and the AHEAD sample (born 1923 and earlier) because the ages at which they enter the sample are past normal retirement ages. In addition, we use restricted data on Social Security earnings to compute a measure of lifetime earnings for all cohorts and for the HRS cohort only, we use restricted data from employers on pension wealth to construct a measure of present discounted pension wealth at age 62 and use it as a control to test sensitivity of our marriage estimates to the inclusion of Social Security and pension wealth measures. Marital history variables were derived based on the raw HRS files and most other variables used in the study are from the RAND HRS Data file. The RAND HRS Data file is an easy to use longitudinal data set based on the HRS data. It was developed at RAND with funding from the National Institute on Aging and the Social Security Administration. We discuss our measurement of the key variables of interest in this analysis and describe our estimate methods in the remaining paragraphs of this section.

Marital History. One goal of this study is to examine whether utilizing detailed assessments of individuals' marital histories better illuminate the associations between marriage and wealth levels near retirement. We create marital status categories based on current marital status, reports of type of past marriage dissolution (widow, divorce) and remarriages, and the number of these marital events to form ten mutually exclusive categories comprised of five married categories and five single categories. The five married categories are: continuously married (currently married and no past marital shocks), remarried after one divorce, remarried after one widowing, remarried after more 
than one shock (divorce or widowing), remarried after one unknown type of marriage shock (a separation occurred but the respondent did not respond if it was a divorce or widowing). The five single categories are: never married, divorced once, widowed once, divorce and/or widowed more than one time, one shock but of an unknown type (respondent did not respond if it was a divorce or widowing). We group partners in with singles (1,144 respondents) and separated in with married respondents ( 822 respondents) and include categories for missing information on past marital shock type or date (217 respondents) and unknown current marital status (250 respondents).

To evaluate the different features of an individual's marital history, we also calculate the total duration spent married across the lifespan and the timing of the first marital disruptions or shocks. We classify age at first shock into the following categories: age less than or equal to 25, ages 26 to 35, ages 36-45 and ages 46 and over. We split 20 years of prime earnings (and savings) years into those likely capturing years before savings has likely been initiated and years in which most households begin savings (Zissimopoulos and Hurd, 2003).

Lifetime earnings. The data from the first wave of the survey are linked with Social Security earnings records. The earnings data for the HRS cohort are based on historical earnings from 1951-1991 reported to the Social Security Administration and are available for 9,539 HRS respondents. ${ }^{1}$ Earnings data for the War Babies cohort are available for 1,330 respondents from years 1951-1997 and for the Early Baby Boomers cohort are available for 1,620 respondents from years 1951-2003. The administrative records are accurate and less subject to measurement error than self-reported earnings from household surveys and cover a long history of earnings. There are also several shortcomings. The level of earnings is reported up to the Social Security maximum. This maximum changed over time as did the number of individuals whose earning were above the maximum. For example, in 1951, 1.4 percent of HRS respondents with matched record had earnings that exceeded the maximum. This percentage increased over the years to reach a maximum of 26.6 percent in 1971 and then decreased to 5.2 percent in 1991. In addition, individuals employed in a sector not covered by Social

\footnotetext{
${ }^{1}$ See Haider and Solon (2000) for a discussion of characteristics of individuals with and without matched Social Security records.
} 
Security have no earnings records for the years he or she is employed in the uncovered sector. 2

We use Social Security earnings to measure lifetime labor income. Lifetime earnings are calculated as the present discounted value ( 3 percent real interest rate) of real Social Security earnings adjusted to 2004 dollars using the CPI-U-RS, and we adjust for the upper truncation of Social Security earnings. We examine the relationship of Social Security earnings and wealth controlling for education to assess its relationship to wealth with the understanding that it may be a noisy measure of actual lifetime earnings. We include in multivariate models of wealth this measure for each individual in the household in a log functional form.

Mortality Risk and Risk Aversion. Mortality risk is the respondent's subjective survival assessment of living to age 75 on a zero to 100 scale and we include it in empirical models as a categorical variable: zero, 1 to 49, 50 (reference group) 51 to 99 and 100. The measure of risk aversion is an indicator for being rated at the least and second-least risk averse levels in a four-point scale of risk aversion. In other words, this is the group that is more tolerable of risk. The basis for categorizing the level of risk aversion is based on a series of questions that ask the respondent to choose between pairs of jobs where one job guarantees current family income and the other offers the chance to increase income and carries the risk of loss of income.

Wealth. Our main outcome measure is wealth at year of entry into the survey for our three birth cohorts: 1992 for the HRS birth cohort (1931-1941), 1998 for the War Babies birth cohort (1942 - 1947) and 2004 for the Early Baby Boom birth cohort (19481953). Total wealth is computed as the sum of wealth from real estate, businesses, IRAs, stocks, bonds, checking accounts, CDs and housing less the value of the mortgage, home loans and other debt. Missing data on wealth are imputed and the methods are described in RAND HRS Version G. The main models include an indicator for pension ownership and type (defined benefit, defined contribution or both). In subsequent analysis for the HRS cohort, the present, discounted value of Social Security wealth and pension wealth at age 62 are included in models as covariates to control for substitution between financial and housing wealth and other wealth. Social Security wealth is computed as

\footnotetext{
${ }^{2}$ In 1996, 92\% of non-self-employed wage and salary workers were covered by Social Security.
} 
combined wealth for married couples and individual wealth for single individuals. It is based on Social Security earnings data for respondents where the information is available and based on self-reported data otherwise. Pension wealth is derived from the HRS Wave 1 Pension Plan Detail Data set for respondents who provided the names and addresses of their employers and HRS obtained the most recent Summary Plan Description. Pension wealth estimation is based on the assumptions of a 6.3 percent interest rate, 5 percent wage growth rate and 4 percent inflation rate which corresponds to the Social Securities 'medium' projection (in contrast to high or low projections). For all other respondents, pension wealth is imputed based on the self-reported data.

Multivariate Model. We use linear regression methods to model log wealth as a function of 10 marriage categories (defined above), with continuously married as the reference group and included as gender specific variables. Also included is a continuous variable for total year spent in the married state, and five age at first separation categories including a missing age indicator (ages 26-35 excluded). Log lifetime earnings are included for males and females separately. Other individual level variables included as gender specific variables are mortality risk, risk aversion, race as an indicator for black, indicators for the highest educational degree achieved include: none; high school or GED (reference group); some college; bachelor's, master's and Ph.D., J.D., M.D. degrees. Household variables include number of children categorized as none, one to three (reference group), four or more; pension ownership and type and in some models log Social Security wealth at age 62 (described above) and log pension wealth at age 62 . We check the sensitivity of the main results to the exclusion of Social Security and pension wealth by estimating the main model for the HRS cohort and including the expected, discounted value of pension wealth at age 62 and Social Security wealth at age 62 . We estimate the model pooled over all birth cohorts, and by birth cohort.

\section{Results}

We first describe the distribution of marital status types that takes into account current marital status, type of past marital disruption (divorce or widowing) and number of disruptions and the length of years spent married and the age of the first marital disruption (if any). We then analyze wealth by these measures of marriage and then 
examine lifetime and current income differences across marriage groups. Next we estimate multivariate models of wealth levels near retirement as function of our marriage variables of interest and a rich set of control variables. Finally, we explore financial literacy as an explanation for the large wealth difference we see for women across marital groups and the sensitivity of our estimation results to the inclusion of Social Security and pension wealth.

Current Marital Status and Marital History. Table 1 shows the distribution of current marital status, number of previous marriages, divorces and widowings and age of first separation for the three birth cohorts separately and together holding age constant ages 51-56. Only about half of marriages are first marriages and more so for the HRS cohort (55.5 percent) than for the War Babies (52.9 percent) and EBB cohort (45.2 percent). Remarriage rates are high at 21.7 percent and about equal for all cohorts. The large difference in continuously married rates between HRS and EBB cohorts is primarily due to the difference in divorce rates (11.4 percent for HRS and 17.5 percent for EBB) and to a smaller extent, percent never married. The EBB cohort is also more likely to have two or more divorces (11.8 percent) than WB (8.9 percent) or HRS (7.3 percent). Among respondents age 51 to 56 that experienced a marriage separation (divorce or widowing), about 35 percent experience the first shock at ages 26 to 35 . There is interesting cohort differences with EBB cohort more likely to experience the shock at younger ages compared to the WB and HRS cohorts. For example, among those that experience a shock, 26.8 percent of EBB cohort experienced the shock age 25 or younger while this percentage is 19.6 for the HRS and 22.6 for the WB cohorts. Because of the greater likelihood of experiencing a shock at a young age, we find that 16.9 percent of the EBB cohort had marriages lasting less than 10 years while this percentage is only 7.4 for the HRS cohort and 11.8 for the WB cohort. Table 2 combines current marital status with past marital events for all cohorts ages 51 to 61 to yield ten mutually exclusive categories and two categories of missing marriage shock type. These are the categories that enter our model for wealth (by gender). Like Table 1, Table 2 shows the diversity of marriage experiences of older adults. Among respondents age 51 to 56, 16.3 percent are remarried after divorce while another 9 percent never remarried after divorce. About equal percentages of respondents remarry after multiple shocks as stay single (5.6 versus 
5.3 percent respectively). Few in this age range are widowed. About 2 percent are remarried widows and about 3 percent are single widows. The most striking difference between men and women (results not shown in Tables) is that men are more likely to be continuously married than women (56.8 vs. 49.6 percent respectively) and remarried after one divorce (19.0 vs. 13.6 percent respectively). In sum, the marriage experiences of individuals age 51-56 are very diverse with less than half of all individuals experiencing one continuous marriage. Moreover, the experience of successive birth cohorts is one of more divorces that do not end in remarriage and occurring at younger ages.

Wealth and Marital Status, Duration and Timing of Disruptions. The first panel of Table 3 shows median wealth for three cohorts ages $51-56$ by the 10 marriage categories. Given the measure of wealth is household wealth, it is not surprising that married couples have more wealth than singles but the difference is very large. Married couples have almost 4 times the wealth as singles, and close to 5 times the wealth among the EBB cohort. Examining mean wealth (panel 2 in Table 3) we see that couples have about 2.5 times more wealth than singles and closer to 3 times more wealth among the EBB cohort. All else equal, what an equivalent amount of wealth for a single person compared to a married person should be is difficult to assess. While we have widely used measures of household income based on equivalence scales, no single accepted measure for wealth exists. Moreover, when considering consumption in retirement, couples may accumulate vastly more than singles to guard against a surviving spouse outliving the resources. Among the singles, median wealth amounts vary by which cohort we examine. Among the HRS, never married (no past shock), divorced (one time) and widowed (one time) have about the same level of wealth (e.g. approximately $\$ 40,000$ ) and individuals experiencing more than one marital disruption have less wealth (approximately \$29,000). Among the War Babies singles, it is both the never married and multiple event singles that hold less wealth than the divorced and widowed. Among the EBB, there is very little difference in wealth levels among the categories of singles. Among married couples, continuously married couples hold more wealth than remarried couples. For example, HRS couples remarried after divorce have about 75 percent the wealth that continuously married couples have and EBB couples remarried after divorce have about 60 percent the wealth that continuously married couples have. The lower 
wealth levels are consistent with marriage shocks involving unexpected expenses large enough that increased savings does not compensate for them, and with the hypothesis that marriage disruptions complicate financial planning. It is also the case that remarried couples have fewer years of total marriage. In sum, generally we see that continuously married couples hold the greatest amount of wealth, even more than remarried couples, and singles experiencing more than one marital disruption have the lowest amount.

If marriage leads to higher wealth due to economies of scale (all else equal) and because marriage produces health then the longer time spent in the married state should be associated with higher levels of wealth (again, all else equal). Table 4 show median wealth by duration of marriage: those with less than 10 years of marriage, 10 years or more of marriage and zero years of marriage (never married) controlling for whether the respondent is currently married or currently single. Both married and singles with 10 years of marriage or more have about two times the amount of median wealth as those with less than 10 years of marriage. Table 4 also shows median wealth levels by age at which the first marriage disruption occurred (divorced or widowing). Among remarried couples, there is little difference by age at which the disruption occurred. In contrast, among singles, age of disruption is positively associated with median wealth levels. That is, the later the age of disruption, the higher the wealth level at the median.

Lifetime Earnings and Marriage Events. One central explanation to the large differences in wealth levels near retirement by marital status and even comparing continuously married to remarried individuals may be differences in permanent earnings whether it be the case that marriage causes higher earnings or that higher ability people are more likely to marry and less likely to divorce. Table 5 shows mean lifetime earnings and current earnings for males and females by current marital status and marriage history. Among married males, there is little difference in lifetime earnings for those continuously married and those who remarry after a single divorce or widowing. For example, men remarried after a divorce, have about $\$ 980,000$ in lifetime earnings and continuously married men have just over one million dollars in lifetime earnings. The $\$ 24,000$ difference in lifetime earnings will not be able to explain all of the $\$ 60,000$ difference in mean wealth between remarried and continuously married men. Remarried males with two or more past disruptions have about $\$ 140,000$ less lifetime earnings than 
continuously married males, which could only explain a small part of the large wealth differences between this group and the continuously married group. On average, single men have lower lifetime earnings than married men. Among single men, the most outstanding difference in lifetime earnings is for never married men, who have only $\$ 600,000$ in lifetime earnings compared to over $\$ 840,000$ in lifetime earnings for divorced men. Lifetime earnings among singles women compared to married women are much different then men. Single women have higher lifetime earnings than married women with never married women having the highest (approximately \$560,000). Remarried women have higher lifetime earnings than continuously married women, which is consistent with lower labor force participation of married women relative to single women. The pattern for current earnings is similar. Continuously married men (women) have similar earnings as men (women) remarried after a divorce. Earnings for widows are lower likely reflecting older ages. Single men have lower earnings than married men, and single women have higher earnings than married women, consistent with prior research on this topic. In sum, while lifetime earnings and current earnings are likely important factors in wealth differences between married and unmarried individuals, they are unlikely to explain more than a small part of the wealth differences between continuously married and remarried men and women.

Multivariate Model Results. Frequency distributions of the categorical covariates included in the multivariate linear regression models of log wealth are provided in the Appendix Table by marriage categories and for all. Our covariates of interest are the 10 marriage categories (based on current status and past events), with continuously married as the reference group, the number of total year spent in the married state, the five age at first separation categories (ages 26-35 excluded), and all these variables are included separately for males and females. Also included for males and females separately are log lifetime earnings, current earnings, mortality risk, risk aversion, race and education. Household variables include number of children, pension ownership and type and entry birth cohort. We check the sensitivity of the results to the exclusion of pension wealth and Social Security wealth by estimating the main model for the HRS cohort and including the expected, discounted value of pension wealth and Social Security wealth at age 62. The first column of Table 6 shows estimation results for total non-pension wealth, 
the second column shows results for non-housing wealth and the third column shows results for housing wealth.

\section{Current Marital Status and Past Marital Events}

One finding based on model estimates presented in Table 6 is that for both men and women, the wealth differences between continuously married and remarried men and women disappear once we include our control variables. An exception is that remarried men with two or more disruptions have 45 percent less wealth than continuously married couples and this is primarily due to much less housing wealth (column 3). As the Appendix table shows, there are some differences between remarried men (women) and continuously married men (women) that in part explain the wealth differences we saw in Table 3. Remarried men and women are less likely to have a college education or higher. In the models, higher education is associated with greater wealth and one mechanism through which this may be operating (holding permanent and transitory income constant) is financial literacy (Lusardi and Mitchell, 2007). They are also more likely to have 4 or more children, which in the models is associated with lower wealth. While the effect of children on assets is complicated, in terms of consumption, expenditure on child-related commodities will increase with the number of children and may alter the allocation of time to the labor market. Other covariates such as mortality risk, risk aversion and financial planning horizon (our proxy for time rate of preference) are generally the same across continuously married and remarried groups with the exception that remarried men after a widowing report a lower probability of living to 75 than other married men (consistent with holding less wealth) and remarried women after a widowing are the least risk averse (consistent with holding less wealth).

Single men and women hold less wealth than continuously married couples as expected given their consumption needs in retirement will be less than that of a married couple. Never married men hold 73 percent less wealth, divorced men hold 99 percent less wealth, single men with two or more marriage events hold 130 percent less wealth and widowers do not have statistically significant less wealth than continuously married couples. Never married women hold 198 percent less wealth, divorced women hold 152 percent less wealth, single women with two or more marriage events hold 174 percent less wealth and widows have 129 percent less wealth than continuously married couples. 
For single men, it is not clear that their level of wealth compared to married men would translate into lower consumption in retirement, particular for never married men. For single women, however, it is clear that their wealth levels are substantial lower than continuously married women. One explanation for the gender differences we see (given we are controlling for lifetime earnings, current earnings, mortality risk and many other differences) is children most often reside with the mother when a marriage dissolves and the higher consumption needs of a household with children may not be fully compensated by alimony or child support payments. To maintain consumption, the household may reduce savings. Another explanation may be financial literacy and we return to examining this explanation later. Comparing the results in this table to the mean wealth results in Table 3 we see that difference in wealth levels between married and single individuals declines substantially. Recall that mean results revealed 2.5 times more wealth for married couples than singles. However, even with income controls (measured with lifetime earnings and current earnings), controls for mortality risk, risk aversion and time rate or preference (measured by financial planning horizon), the effect of marriage (particularly for women) is quantitatively important.

\section{Years Married and Age of Marital Disruption}

Each additional year spent married is associated with a 4 percent increase in total non-pension wealth for both men and women. This is a substantial effect when you consider that the average number of years spent married for a continuously married couple is 30 years (26 years for remarried couples) and only 16 years for a divorced individual. The effect is slightly higher on housing wealth (6.0 and 5.4 percent for men and women respectively) than non-housing wealth (3.2 and 3.8 percent for men and women respectively), which is consistent with the hypothesis that marriage brings economies of scale in consumption. The age at which the first marriage disruption occurred has no effect on the total wealth of men but for men with a disruption at ages 46 and older, housing wealth is 110 percent lower compared to men that experienced a disruption between ages 26 and 35. Among women total wealth is 39 percent lower if the marital disruption occurred between ages 36 and 45 compared to a disruption between ages 26 and 35 and the negative effect is on housing wealth.

Other Predictors of Wealth 
Income, mortality risk, risk aversion and financial planning horizon (our proxy for time rate of preference) all have a significant effect on wealth levels near retirement in the expected direction. A one percent increase in the lifetime earnings of men increase wealth by 0.41 percent and a one percent increase in the lifetime earnings of women increase wealth by 0.11 percent. This is a large effect for men. The effect of a one percent increase in current earnings is substantial smaller than for lifetime earnings and is 0.04 percent for both men and women. A high mortality risk (a zero subjective survival of living to 75) is associated with substantially lower wealth levels (83.6 and 95.4 percent less wealth for men and women respectively) and a high tolerance for risk is associated with 31 percent less wealth for men. We interpret the financial planning horizon as a proxy for time rate of preference and find that as the horizon increases so does wealth. Finally, as noted earlier, high education (college or more) is associated with large increases in wealth and more children, less wealth. For example, a male college graduate has 110 percent more wealth than a high school graduate (107 percent more for females). For men, only the effect of being college educated has a magnitude similar to that of being not married. For women, no other characteristic has as large of an effect as being single has on wealth levels but with education still having a large effect.

\section{Financial Literacy}

One explanation for the large wealth differences of single women compared to married women even with rich controls is differences in financial literacy. This may be particularly important for previously married women (compared to never married women) who may not have invested in understanding complex financial decisions while married if the husband, and not the wife, specializes in financial decision-making. While financial literacy has been shown to vary substantial with education (Lusardi and Mitchell, 2007), for which we control in our models, if it is the case that spouses specialize, then controlling for education, we would expect a difference in financial literacy by marriage category. Fortunately in the 2004 wave of the HRS, the Early Baby Boomer cohort was asked three questions geared toward assessing their financial literacy. We examine the third question that was designed to elicit ability to make complex financial decisions. Table 7 shows the financial literacy question that was asked and the percent of correct responses by marital status controlling for education. We find that the 
percent of respondents who answered the question correctly is much lower for divorced and widowed respondents than for married respondents at all education levels and even among college graduates. In contrast, never married individuals are more likely to answer correctly than then divorced and widowed individuals. These results are consistent with the hypothesis of specialization in financial literacy within marriage. More research in this area may shed light on some of the marriage differences we see.

\section{Pension and Social Security Wealth}

Our measure of wealth (housing and non-housing) is somewhat narrow in that it does not include future claims on pension and Social Security wealth that may vary by current marital status and past marital events. Table 8 shows mean values of the present, discounted value of Social Security wealth and pension wealth as of age 62 and mean value of housing and financial wealth for the HRS cohort (all in \$2004). Mean Social Security wealth is about 2 times higher for married males than single males and about 2.5 times higher for married women than single women. Social Security wealth is lowest for widowed females. Compared to housing and non-housing wealth, Social Security wealth is more important for singles than married individuals. For example, continuously married males have mean housing and non-housing wealth that is almost 2 times their Social Security wealth while for divorced males, mean housing and non-housing wealth is about 1.5 time more than their mean Social Security wealth. Adding in pension wealth we find that for continuously married men housing and financial wealth is about 0.8 pension plus Social Security wealth while for divorce men, Social Security and pension wealth is almost 2 times the mean amount of housing and financial wealth. For divorced women, Social Security and pension wealth is just over 2 times the mean housing and financial wealth. In sum, once we consider Social Security and pension wealth, the mean wealth differences between married and single respondents decrease. We check the sensitivity of our estimates of our marriage covariates of interest in Table 6 to the inclusion of controls for Social Security wealth and pension wealth. We find the estimated negative effect on wealth of being a divorced male or a male with two or more past shocks declines ( -0.99 to -0.70 and -1.32 to -1.04 respectively). Among women, we find the negative effect on wealth of being never married declines $(-1.98$ to -1.49$)$. No 
other estimates of marriage categories change substantially with the inclusion of these measures (results not shown).

\section{Conclusion}

There are many pathways through which marriage may affect wealth and the strength of the relationship between marriage and wealth described in the empirical literature suggests its importance as an area for further study. This study expands our understanding of how marriage and wealth are related by analyzing a lifetime of marriage events, the timing of marriage events and duration of years spent married, and by examining a rich set of covariates that a lifecycle model of savings predicts to affect wealth and that may vary by marriage including lifetime and current earnings, education, mortality risk, risk aversion, time rate of preference, children and other demographics. We find the marriage experiences of individuals nearing retirement are very diverse with less than half of all individuals experiencing one continuous marriage. Moreover, the experience of successive birth cohorts is one of more divorces that do not end in remarriage and occurring at younger ages. Continuously married couples hold the greatest amount of wealth, even more than remarried couples, and singles experiencing more than one marital disruption have the lowest amount of wealth. Lifetime earnings and current earnings are important factors in wealth differences between married and unmarried individuals; they at most explain only a small part of the wealth differences between continuously married and remarried men and women.

Estimation results from models of log wealth with rich controls, reveal no wealth differences between continuously married and remarried couples in part due to controls for the lower education and higher number of children of remarried individuals compared to continuously married individuals. Single men have lower wealth levels than continuously married men but the magnitude is such that it may not be the case that their level of wealth compared to married men would translate into lower consumption in retirement, particular for never married men. For single women, however, it is clear that their wealth levels are substantial lower than continuously married women. One explanation for the gender differences (given we are controlling for lifetime earnings, current earnings, mortality risk and many other differences) may be that children most 
often reside with the mother when a marriage dissolves and the higher consumption needs of a household with children may not be full compensated by alimony or child support payments thus to maintain consumption, the household may reduce savings. Another explanation for the large wealth differences of single women compared to married women is financial literacy. This may be particularly important for previously married women (compared to never married women) who may not have invested in understanding complex financial decisions while married if spouses choose one (e.g. the husband) to specialize in financial decision-making. Finally, we find the more time spent married, the higher is wealth and that for women a marital disruption between the ages of 36 and 45 reduced housing wealth at older ages substantially.

Our primary measure of wealth (housing and non-housing) does not include future claims on pension and Social Security wealth that may vary by current marital status and past events. Once we include Social Security and pension wealth in our measure of total wealth, the mean (and median) wealth differences between married and single individuals decrease but inclusion of these measures in our model does not change our main substantive findings.

Our model explains 28 percent of the variance in wealth across household (30 percent for the HRS cohort in models with pension and Social Security wealth included) thus much remains unexplained. If the remaining heterogeneity is correlated with marriage, our results may still be biased. Future work will take advantage of the long HRS panel to examine changes in wealth and savings as a result of marriage status changes and utilizing panel econometric techniques to control for unobserved heterogeneity. Finally, we find interesting cohort differences (model based results not shown) that deserve future study. For example, in model-based estimation, we find that remarried men from the Early Baby Boom cohort have less wealth (69 percent) than continuously married EBB men. Second, divorced EBB women have about 100 percent less wealth than continuously married EBB women and this effect is substantially smaller than for the HRS cohort (193 percent). Given the higher divorce rate and earlier age of divorce among the EBB cohort compared to earlier cohorts, an understanding of how marriage events impact savings may become increasingly important for understanding the economic security of these soon to be retired individuals and families. 


\section{References}

Becker, Gary S. 1981. A Treatise on the Family. Cambridge: Harvard University Press. Browning, Martin and Annamaria Lusardi, 1996, "Household Saving: Micro Theories and Micro Facts," Journal of Economic Literature, XXXIV, pp 1797-1855.

Cherlin, A. 1992. Marriage, Divorce and Remarriage. Cambridge, MA: Harvard University Press.

Coombs, R.H. (1991). Marital status and personal well-being: A literature review. Family Relations, 40, 97-102.

Dynan, Karen, 1993. "How Prudent are Consumers?” Journal of Political Economy 101(6): 1104-1113.

Gove, W.R. (1973). Sex, marital status, and mortality. American Journal of Sociology, 79, 45-67.

Gustman, Alan and F. Thomas Juster, 1996, "Income and Wealth of Older American Households," in Eric Hanushek and Nancy Maritato, Assessing Knowledge of Retirement Behavior, Washington D.C.: National Academy Press.

Haider, Steven and Gary Solon, 2000, "Non-Response Bias in the HRS Social Security Files," RAND DRU-2254-NIA

Hill, Martha. 1979. The Wage Effects of Marital Status and Children. Journal of Human Resources 14(4): 579-94.

House, J.S., Landis, K.R., \& Umberson, D. (1988). Social relationships and health. Science, 241, 540-545.

Hubbard, R. Glenn, Jonathan Skinner and Stephen D. Zeldes, 1995, "Precautionary Saving and Social Insurance," Journal of Political Economy, 103 (2), pp. 360399.

Korenman, Sanders and David Neumark. 1991. Does Marriage Really Make Men More Productive? The Journal of Human Resources 26(2): 282-307.

Lillard, Lee and Linda Waite. 1995. Till Death Do Us Part: Marital Disruption and Mortality. American Journal of Sociology, 100: 1131-1156.

Loughran, David and Julie Zissimopoulos. 2007. Why Wait? The Effect of Marriage and Childbearing on the Wage Growth of Men and Women. RAND Working Paper WR-482.

Lundberg, Shelly and Elaina Rose. 2002. The Effects of Sons and Daughters on Men's Labor Supply and Wages. Review of Economics and Statistics 84(2): 251-68.

Lupton, Joseph and James Smith. 2000. Marriage Assets and Savings. Mimeo.

Lusardi, Annamaria and Olivia Mitchell. 2007. "Baby Boomer retirement security: The roles of planning, financial literacy and housing wealth." Journal of Monetary Economics 54: 205-224.

Mincer, Jacob. 1978. Family Migration Decisions. Journal of Political Economy 86(5): 749-773.

Modigliani, Franco and Brumberg, Richard, 1954, "Utility Analysis and the Consumption Function: An Interpretation of Cross-Section Data," in K. Kurihara, ed., PostKeynesian Economics, New Brunswick: Rutgers University Press

Pienta, A., Hayward, M. D., \& Jenkins, K. R. (2000). Health consequences of marriage for the retirement years. Journal of Family Issues, 21, 559-586.

Siegel, J.S. (1993). A generation of change: A profile of America's older population. New York: Russell Sage Foundation. 
Smith, James P. 1988. Poverty and the Family, in Divided Opportunities: Gary Sandefur and Marta Tienda editors, Plenum Publishing Corporation.

Smith, James P., 1995, "Racial and Ethnic Differences in Wealth," Journal of Human Resources 30: S158-S183.

Venti, Steven F., and David A. Wise, 1996, "Lifetime Income, Saving Choices, and Wealth at Retirement," presented at the Symposium to Honor of F. Thomas Juster, December, Ann Arbor.

Venti, Steven F. and David A. Wise, 2000, "Choice, Chance and Wealth Dispersion at Retirement,” NBER Working Paper \#7521.

Wilmoth, Janet and Gregor Koso. 2002. Does Marital History Matter? Marital Status and Wealth Outcomes Among Pre-retirement Adults, Journal of Marriage and Family 64: 254-268.

Zissimopoulos, Julie and Michael Hurd, 2003. Saving for Retirement: Wage Growth and Unexpected Events. Manuscript under review. 
Table 1-Distribution of Current Marital Status, Number of Marital Disruptions, Age of First Disruption and Year Married by Cohort For Ages 51-56

(percent distribution)

\begin{tabular}{lrrrr}
\hline & HRS & WB & EBB & All \\
\hline Marital Status & & & & \\
Missing & 0.16 & 0.93 & 1.23 & 0.58 \\
Married continuously* & 55.53 & 52.93 & 45.15 & 52.41 \\
Remarried* & 21.84 & 20.91 & 21.80 & 21.66 \\
Partnered & 2.83 & 3.12 & 4.22 & 3.24 \\
Divorced & 11.42 & 14.34 & 17.54 & 13.52 \\
Widowed & 4.65 & 3.17 & 3.30 & 4.03 \\
Never Married & 3.57 & 4.60 & 6.76 & 4.57 \\
Number of Divorces & & & & \\
Missing & 0.14 & 1.15 & 1.91 & 0.78 \\
0 divorces & 66.70 & 62.23 & 56.60 & 63.31 \\
1 divorce & 25.89 & 27.70 & 29.67 & 27.19 \\
$2+$ divorces & 7.26 & 8.92 & 11.81 & 8.73 \\
Age at First Separation & & & & \\
No sep & 60.02 & 57.58 & 51.03 & 57.28 \\
Missing & 1.06 & 1.97 & 2.38 & 1.57 \\
$<=25$ & 7.82 & 9.58 & 13.13 & 9.49 \\
$26-35$ & 13.68 & 15.60 & 17.26 & 14.94 \\
$36-45$ & 11.42 & 11.66 & 11.18 & 11.40 \\
$46+$ & 6.00 & 3.61 & 5.01 & 5.31 \\
Years Married & & & & \\
Missing & 5.05 & 4.11 & 3.98 & 4.60 \\
$<10$ & 7.35 & 11.77 & 16.87 & 10.59 \\
$10+$ & 87.60 & 84.13 & 79.16 & 84.81 \\
\hline N & 5550 & 1827 & 2514 & 8251 \\
\hline SOUCE: Aur & & & & \\
\hline
\end{tabular}

SOURCE: Authors' calculations based on the 1992 (HRS cohort), 1998 (War Babies, WB cohort) and 2004 (Early Baby Boomers, EBB cohort) HRS.

NOTE: Sample is respondents from each cohort ages 51 to 56. Columns may not add to totals due to rounding. ' $*$ ' indicates that this category includes separated individuals.

Table 2- Distribution of Marriage Disruption by Current Marital Status For Ages 51-56 (percent distribution)

\begin{tabular}{lrr}
\hline & Current Married & Current Single \\
\hline Missing & 0.61 & 0.47 \\
No past shock (continuously/never married) & 53.18 & 4.57 \\
1 divorce & 16.31 & 8.97 \\
2+ (divorce or widow) & 5.62 & 5.30 \\
1 widowing & 1.66 & 2.87 \\
1 unknown disruption & 0.44 & 0.01 \\
Total & 77.82 & 22.18 \\
\hline
\end{tabular}

SOURCE: Authors' calculations based on the 1992-2004 HRS.

NOTE: Sample 8251 respondents ages 51 to 56 . Cell total equals 100. 
Table 3- Mean and Median Wealth by Marriage Categories and Cohort For Ages 51-56

(\$2004)

\begin{tabular}{lcccccccc}
\hline & \multicolumn{2}{c}{ HRS } & \multicolumn{2}{c}{ WBB } & \multicolumn{2}{c}{ EBB } & \multicolumn{2}{c}{ All } \\
\hline & \multicolumn{7}{c}{ Median Wealth $(\$)$} \\
\cline { 2 - 9 } No past shock & Married & Single & Married & Single & Married & Single & Married & Single \\
1 divorce & 153,671 & 41,419 & 170,120 & 19,963 & 214,000 & 33,052 & 167,522 & 35,745 \\
2+ shocks & 119,368 & 39,836 & 114,629 & 73,661 & 127,500 & 44,700 & 119,200 & 47,091 \\
1 widowing & 84,420 & 29,020 & 112,488 & 18,516 & 107,850 & 35,000 & 96,952 & 31,275 \\
Total & 108,295 & 39,407 & 209,873 & 67,238 & 96,050 & 41,250 & 11,451 & 46,233 \\
& 141,140 & 38,253 & 152,761 & 45,597 & 180,500 & 37,300 & 151,693 & 39,275 \\
& & & & \multicolumn{1}{c}{ Mean Wealth $(\$)$} & & & \\
No past shock & 337,950 & 202,953 & 380,121 & 104,681 & 447,794 & 137,503 & 370,013 & 160,074 \\
1 divorce & 278,877 & 130,393 & 310,180 & 202,923 & 425,296 & 157,449 & 324,134 & 153,450 \\
2+ shocks & 213,412 & 96,524 & 368,230 & 85,170 & 323,913 & 127,979 & 273,731 & 105,444 \\
1 widowing & 262,738 & 102,029 & 367,699 & 143,953 & 143,438 & 244,340 & 253,890 & 133,284 \\
Total & 315,726 & 130,487 & 364,822 & 149,825 & 425,776 & 150,936 & 350,476 & 140,403 \\
\hline
\end{tabular}

SOURCE: Authors' calculations based on the 1992-2004 HRS.

NOTE: Sample is 8158 respondents ages 51 to 56. Excludes 93 respondents with unknown type of marriage disruption.

Table 4-Median Wealth by Age of Marital Change, Year Married, Cohort: Ages 51-56 (\$2004)

\begin{tabular}{|c|c|c|c|c|}
\hline & HRS & WB & EBB & $\overline{\text { ALL }}$ \\
\hline Age of First Shock & \multicolumn{4}{|c|}{ Currently Married } \\
\hline No separation & 153,671 & 174,171 & 222,000 & 172,099 \\
\hline$<=25$ & 101,568 & 94,897 & 106,846 & 102,157 \\
\hline $26-35$ & 112,517 & 139,684 & 112,100 & 117,332 \\
\hline $36-45$ & 127,785 & 109,363 & 133,009 & 125,438 \\
\hline $46+$ & 98,101 & 183,718 & 32,400 & 93,307 \\
\hline \multicolumn{5}{|l|}{ Years Married } \\
\hline 0 & 17,280 & 13,193 & 28,500 & 20,511 \\
\hline$<10$ & 71,201 & 122,845 & 83,000 & 85,798 \\
\hline $10+$ & 148,395 & 162,019 & 194,500 & 161,546 \\
\hline Age of First Shock & \multicolumn{4}{|c|}{ Currently Single } \\
\hline No separation & 39,572 & 18,516 & 31,603 & 32,865 \\
\hline$<=25$ & 13,586 & 13,598 & 32,400 & 21,089 \\
\hline $26-35$ & 26,579 & 39,548 & 32,500 & 31,286 \\
\hline $36-45$ & 43,641 & 76,265 & 43,000 & 49,525 \\
\hline $46+$ & 60,188 & 111,099 & 77,375 & 70,565 \\
\hline Years Married & & & & \\
\hline 0 & 41,551 & 19,963 & 21,671 & 29,883 \\
\hline$<10$ & 14,774 & 31,304 & 30,750 & 25,335 \\
\hline $10+$ & 46,167 & 72,301 & 46,500 & 50,787 \\
\hline
\end{tabular}

SOURCE: Authors' calculations based on the 1992-2004 HRS.

NOTE: Sample is 8251 respondents ages 51 to 56. 
Table 5-Mean Lifetime Earnings and Current Earnings by Marital Categories (\$2004)

\begin{tabular}{lrccr}
\hline & \multicolumn{3}{c}{ Males } & \multicolumn{3}{c}{ Females } \\
\hline & Married & Mean Lifetime Earnings (\$) & Married & Single \\
\cline { 2 - 5 } No past shock & $1,000,943$ & 603,643 & 303,586 & 560,647 \\
1 divorce & 977,325 & 843,083 & 387,604 & 462,205 \\
$2+$ shocks & 861,106 & 827,071 & 392,952 & 444,474 \\
1 widowing & 934,577 & 706,314 & 273,472 & 329,973 \\
& \multicolumn{4}{c}{ Current Earnings (\$) } \\
\cline { 2 - 5 } No past shock & Married & Single & Married & Single \\
1 divorce & 45,523 & 24,178 & 18,181 & 24,029 \\
2+ shocks & 41,979 & 28,037 & 20,738 & 26,699 \\
1 widowing & 34,977 & 32,325 & 20,514 & 21,618 \\
SOURCE: Aus & 35,796 & 22,157 & 15,651 & 15,617 \\
\hline
\end{tabular}

SOURCE: Authors' calculations using SS earnings and1992-2004 HRS.

NOTE: Sample is all respondents for current earnings and with matched Social

Security earnings records for lifetime earnings.

Table 6-Models of (Ln) Total Wealth, Non-housing Wealth and Housing Wealth

\begin{tabular}{|c|c|c|c|}
\hline & (1) & (2) & (3) \\
\hline & (Ln) Wealth & (Ln)Non-House & (Ln)Housing \\
\hline Male currently married - 1 div, 0 wid & $\begin{array}{l}-0.094 \\
(0.122)\end{array}$ & $\begin{array}{c}0.008 \\
(0.132)\end{array}$ & $\begin{array}{l}-0.139 \\
(0.160)\end{array}$ \\
\hline Male currently married - 0 div, 1 wid & $\begin{array}{c}0.140 \\
(0.309)\end{array}$ & $\begin{array}{c}0.419 \\
(0.335)\end{array}$ & $\begin{array}{c}0.505 \\
(0.404)\end{array}$ \\
\hline Male currently married - 2 past events & $\begin{array}{c}-0.454 \\
(0.175)^{* *}\end{array}$ & $\begin{array}{l}-0.150 \\
(0.190)\end{array}$ & $\begin{array}{c}-1.216 \\
(0.229)^{* *}\end{array}$ \\
\hline Male currently single - 0 div, 0 wid (never married) & $\begin{array}{c}-0.725 \\
(0.255)^{* *}\end{array}$ & $\begin{array}{c}-0.873 \\
(0.276)^{* *}\end{array}$ & $\begin{array}{c}-1.397 \\
(0.334)^{* *}\end{array}$ \\
\hline Male currently single - 1 div, 0 wid & $\begin{array}{c}-0.989 \\
(0.213)^{* *}\end{array}$ & $\begin{array}{c}-0.773 \\
(0.231)^{* *}\end{array}$ & $\begin{array}{c}-2.056 \\
(0.279)^{* *}\end{array}$ \\
\hline Male currently single - 0 div, 1 wid & $\begin{array}{l}-0.604 \\
(0.394)\end{array}$ & $\begin{array}{c}-0.980 \\
(0.427)^{*}\end{array}$ & $\begin{array}{l}-0.575 \\
(0.515)\end{array}$ \\
\hline Male currently single - 2 past events & $\begin{array}{c}-1.323 \\
(0.231)^{* *}\end{array}$ & $\begin{array}{c}-1.080 \\
(0.251)^{* *}\end{array}$ & $\begin{array}{c}-2.693 \\
(0.303)^{* *}\end{array}$ \\
\hline Female currently married - 1 div, 0 wid & $\begin{array}{l}-0.131 \\
(0.116)\end{array}$ & $\begin{array}{l}-0.045 \\
(0.126)\end{array}$ & $\begin{array}{l}-0.290 \\
(0.152)\end{array}$ \\
\hline Female currently married - 0 div, 1 wid & $\begin{array}{l}-0.244 \\
(0.238)\end{array}$ & $\begin{array}{l}-0.226 \\
(0.258)\end{array}$ & $\begin{array}{l}-0.578 \\
(0.312)\end{array}$ \\
\hline Female currently married - 2 past events & $\begin{array}{l}-0.167 \\
(0.173)\end{array}$ & $\begin{array}{l}-0.053 \\
(0.187)\end{array}$ & $\begin{array}{c}-0.528 \\
(0.226)^{*}\end{array}$ \\
\hline Female currently single - 0 div, 0 wid (never married) & $\begin{array}{c}-1.978 \\
(0.238)^{* *}\end{array}$ & $\begin{array}{c}-2.000 \\
(0.258)^{* *}\end{array}$ & $\begin{array}{c}-2.599 \\
(0.311)^{* *}\end{array}$ \\
\hline Female currently single - 1 div, 0 wid & $\begin{array}{c}-1.524 \\
(0.173)^{* *}\end{array}$ & $\begin{array}{c}-1.975 \\
(0.188)^{* *}\end{array}$ & $\begin{array}{c}-1.980 \\
(0.226)^{* *}\end{array}$ \\
\hline Female currently single - 0 div, 1 wid & $\begin{array}{c}-1.288 \\
(0.211)^{* *}\end{array}$ & $\begin{array}{c}-1.915 \\
(0.229)^{* *}\end{array}$ & $\begin{array}{c}-1.256 \\
(0.277)^{* *}\end{array}$ \\
\hline Female currently single - 2 past events & $\begin{array}{c}-1.740 \\
(0.173)^{* *}\end{array}$ & $\begin{array}{c}-2.039 \\
(0.188)^{* *}\end{array}$ & $\begin{array}{c}-2.429 \\
(0.227)^{* *}\end{array}$ \\
\hline
\end{tabular}




\section{Table 6 cont.-Models of (Ln) Total Wealth, Non-housing Wealth and Housing Wealth}

Male total years spent in married state

Female total years spent in married state

Male age at first separation $<26$

Male age at first separation 36-45

Male age at first separation $>45$

Female age at first separation $<26$

Female age at first separation 36-45

Female age at first separation $>45$

Male age

Male age squared

Female age

Female age squared

Male education less than high school

Male education some college

Male education college plus

Female education less than high school

Female education some college

Female education college plus

Race is black

Race is other

Has no children

Has 4+ children

Male $0 \%$ probability of living to age 75

Male 1-49\% probability of living to age 75

Male 50\% probability of living to age 75

Male $100 \%$ probability of living to age 75

$\begin{array}{ccc}\text { (Ln) Wealth } & (\text { Ln)Non-House } & (\text { Ln)Housing } \\ 0.041 & 0.032 & 0.060 \\ (0.005)^{* *} & (0.006)^{* *} & (0.007)^{* *} \\ 0.044 & 0.038 & 0.054 \\ (0.005)^{* *} & (0.005)^{* *} & (0.006)^{* *} \\ -0.035 & -0.218 & 0.273 \\ (0.171) & (0.185) & (0.224) \\ -0.083 & 0.043 & -0.177 \\ (0.149) & (0.161) & (0.195) \\ -0.364 & -0.313 & -1.096 \\ (0.201) & (0.218) & (0.263)^{* *} \\ -0.201 & 0.049 & -0.202 \\ (0.131) & (0.142) & (0.171) \\ -0.391 & -0.244 & -0.408 \\ (0.137)^{* *} & (0.149) & (0.179)^{*} \\ -0.074 & -0.092 & -0.183 \\ (0.188) & (0.204) & (0.247) \\ -0.370 & -0.391 & -0.345 \\ (0.065)^{* *} & (0.070)^{* *} & (0.085)^{* *} \\ 0.004 & 0.004 & 0.004 \\ (0.001)^{* *} & (0.001)^{* *} & (0.001)^{* *} \\ -0.197 & -0.222 & -0.081 \\ (0.065)^{* *} & (0.071)^{* *} & (0.085) \\ 0.002 & 0.003 & 0.001 \\ (0.001)^{* *} & (0.001)^{* *} & (0.001) \\ -0.997 & -1.323 & -0.962 \\ (0.104)^{* *} & (0.113)^{* *} & (0.137)^{* *} \\ 0.297 & 0.354 & 0.209 \\ (0.101)^{* *} & (0.109)^{* *} & (0.132) \\ 1.107 & 1.331 & 0.902 \\ (0.102)^{* *} & (0.111)^{* *} & (0.134)^{* *} \\ -1.443 & -1.516 & -1.471 \\ (0.091)^{* *} & (0.098)^{* *} & (0.118)^{* *} \\ 0.504 & 0.683 & 0.398 \\ (0.086)^{* *} & (0.094)^{* *} & (0.113)^{* *} \\ 1.072 & 1.462 & 0.978 \\ (0.097)^{* *} & (0.105)^{* *} & (0.127)^{* *} \\ -1.857 & -2.023 & -1.698 \\ (0.069)^{* *} & (0.075)^{* *} & (0.090)^{* *} \\ -0.891 & -1.127 & -1.213 \\ (0.107)^{* *} & (0.116)^{* *} & (0.140)^{* *} \\ 0.120 & 0.164 & -0.226 \\ (0.105) & (0.114) & (0.137) \\ -0.264 & -0.525 & -0.252 \\ (0.055)^{* *} & (0.060)^{* *} & (0.073)^{* *} \\ -0.836 & -1.167 & -0.369 \\ (0.157)^{* *} & (0.170)^{* *} & (0.205) \\ -0.332 & -0.274 & -0.089 \\ (0.123)^{* *} & (0.133)^{*} & (0.161) \\ -0.071 & -0.227 & -0.035 \\ (0.104) & (0.113)^{*} & (0.136) \\ -0.052 & -0.096 & -0.217 \\ (0.112) & (0.121) & (0.146) \\ & & \end{array}$




\section{Table 6 cont.-Models of (Ln) Total Wealth, Non-housing Wealth and Housing Wealth}

Female $0 \%$ probability of living to age 75

Female $1-49 \%$ probability of living to age 75

Female $50 \%$ probability of living to age 75

Female $100 \%$ probability of living to age 75

Male least risk averse

Male 3rd most risk averse

Male 2nd most risk averse

Female least risk averse

Female 3rd most risk averse

Female 2nd most risk averse

Male 5-10yr financial planning horizon

Male >10yr financial planning horizon

Female 5-10yr financial planning horizon

Female $>10 y$ financial planning horizon

Male (ln) SS lifetime earnings

Female (ln) SS lifetime earnings

Male log of current earn - 2004\$

Female log of current earn - 2004\$

Defined benefit only household pensions

Defined contribution only household pensions

Both types of household pensions

Constant
(Ln) Wealth

$-0.954$

$(0.150)^{* *}$

$-0.412$

$(0.111)^{* *}$

$-0.103$

(0.089)

0.089

(0.089)

$-0.308$

$(0.112)^{* *}$

$-0.064$

(0.128)

$-0.004$

(0.117)

0.143

(0.105)

0.081

(0.112)

0.143

(0.099)

0.489

$(0.086) * *$

0.367

$(0.125)^{* * *}$

0.310

$(0.076)^{* * *}$

0.451

$(0.109)^{* * *}$

0.410

$(0.041)^{* *}$

0.113

$(0.018)^{* * *}$

0.036

$(0.009)^{* *}$

0.042

$(0.008) * *$

0.672

$(0.072)^{* *}$

0.618

$(0.073)^{* * *}$

0.776

$(0.073) * *$

12.420

$(1.626)^{* *}$
(Ln)Non-House

$-1.448$

$(0.163)^{* *}$

$-0.636$

$(0.121)^{* *}$

$-0.025$

(0.097)

0.057

(0.096)

$-0.204$

(0.121)

$-0.138$

(0.139)

$-0.086$

(0.126)

0.119

(0.114)

$-0.011$

(0.121)

0.269

$(0.107)^{*}$

0.545

$(0.094)^{* *}$

0.420

$(0.136)^{* *}$

0.441

$(0.082)^{* *}$

0.546

$(0.118)^{* *}$

0.401

$(0.045)^{* *}$

0.117

$(0.020) * *$

0.052

$(0.010)^{* *}$

0.042

$(0.008) * *$

0.531

$(0.078)^{* *}$

0.648

$(0.079)^{* *}$

0.822

$(0.079) * *$

11.891

$(1.762)^{* *}$
(Ln)Housing

$-0.707$

$(0.197)^{* *}$

$-0.211$

(0.146)

$-0.061$

(0.117)

0.071

(0.116)

$-0.593$

$(0.147)^{* * *}$

$-0.262$

(0.168)

$-0.022$

(0.153)

0.040

(0.138)

0.138

(0.146)

0.150

(0.130)

0.595

$(0.113)^{* *}$

0.461

$(0.164)^{* *}$

0.419

$(0.099) * *$

0.416

$(0.143)^{* *}$

0.550

$(0.054) * *$

0.103

$(0.024) * *$

0.010

(0.012)

0.022

$(0.010)^{*}$

1.006

$(0.094)^{* *}$

0.887

$(0.096)^{* * *}$

1.407

$(0.095)^{* *}$

7.150

$(2.128)^{* *}$

Observations

17198

17198

17198

R-squared 0.28

SOURCE: Authors' calculations based on the 1992-2004 HRS.

NOTE: Sample is all respondents. Standard errors given in parentheses. '*' indicates significant at $5 \%$, ' $* *$ ' indicates significant at $1 \%$. Includes missing indicators for marriage categories when type of shock is unknown, other missing data indicators, cohort indicators. 
Table 7-Financial Literacy by Current Marital Status and Education (percent)

\begin{tabular}{lrrrrrr}
\hline & \multicolumn{3}{c}{ Less than High School } & \multicolumn{2}{c}{ High School Graduate } & \multicolumn{2}{c}{ College Graduate } \\
\hline & \% Correct & $\mathrm{N}$ & \% Correct & $\mathrm{N}$ & \% Correct & $\mathrm{N}$ \\
Married continuously* & 6.82 & 88 & 11.01 & 672 & 29.70 & 468 \\
Remarried* & 5.56 & 36 & 10.02 & 419 & 25.47 & 161 \\
Partnered & 0.00 & 13 & 2.25 & 89 & 18.75 & 32 \\
Divorced & 3.45 & 29 & 8.12 & 234 & 16.51 & 109 \\
Widowed & 0.00 & 6 & 6.98 & 43 & 0.00 & 13 \\
Never Married & 9.09 & 11 & 6.17 & 81 & 22.64 & 53 \\
Total & 5.35 & 187 & 9.35 & 1551 & 25.62 & 843 \\
\hline
\end{tabular}

SOURCE: Authors' calculations based on wave 2004 HRS.

NOTE: Sample is all EBB respondents that responded correctly to at least one of the earlier two financial literacy questions. '*' category includes separated. Percent correct is in response to question "Let's say you have 200 dollars in a savings account. The account earns $10 \%$ interest per year. How much would you have in the account at the end of two years?"

Table 8-Mean Wealth by Marriage Disruptions and Current Status For Males and Females - HRS Cohort

$(\$ 2004)$

\begin{tabular}{|c|c|c|c|c|}
\hline & \multicolumn{2}{|c|}{ Males } & \multicolumn{2}{|c|}{ Females } \\
\hline & \multicolumn{4}{|c|}{ Mean SS Wealth at Age $62(\$)$} \\
\hline & Married & Single & Married & Single \\
\hline No past shock & 205,902 & 96,773 & 207,429 & 85,182 \\
\hline 1 divorce & 206,790 & 112,649 & 205,862 & 81,537 \\
\hline $2+$ shocks & 197,520 & 112,461 & 203,704 & 78,045 \\
\hline \multirow[t]{3}{*}{1 widowing } & 199,312 & 97,438 & 198,772 & 67,289 \\
\hline & \multicolumn{4}{|c|}{ Mean Pension Wealth at Age $62(\$)$} \\
\hline & Married & Single & Married & Single \\
\hline No past shock & 257,047 & 161,410 & 92,378 & 159,830 \\
\hline 1 divorce & 243,908 & 200,915 & 141,437 & 127,998 \\
\hline $2+$ shocks & 231,485 & 247,169 & 115,164 & 96,860 \\
\hline \multirow[t]{3}{*}{1 widowing } & 273,915 & 166,181 & 85,819 & 83,236 \\
\hline & \multicolumn{4}{|c|}{ Mean Housing and Financial Wealth $(\$)$} \\
\hline & Married & Single & Married & Single \\
\hline No past shock & 350,628 & 267,090 & 341,279 & 84,913 \\
\hline 1 divorce & 273,115 & 167,190 & 284,112 & 101,631 \\
\hline $2+$ shocks & 198,630 & 163,978 & 212,754 & 102,543 \\
\hline 1 widowing & 337,453 & 153,407 & 229,183 & 133,907 \\
\hline
\end{tabular}

SOURCE: Authors' calculations based on 1992 restricted Social Security earnings data, restricted pension data and the 1992 public release HRS.

NOTE: Sample is HRS birth cohort with non-missing data. 
Appendix Table-Frequency of Model Covariates by Marital Categories-Males (percent distribution)

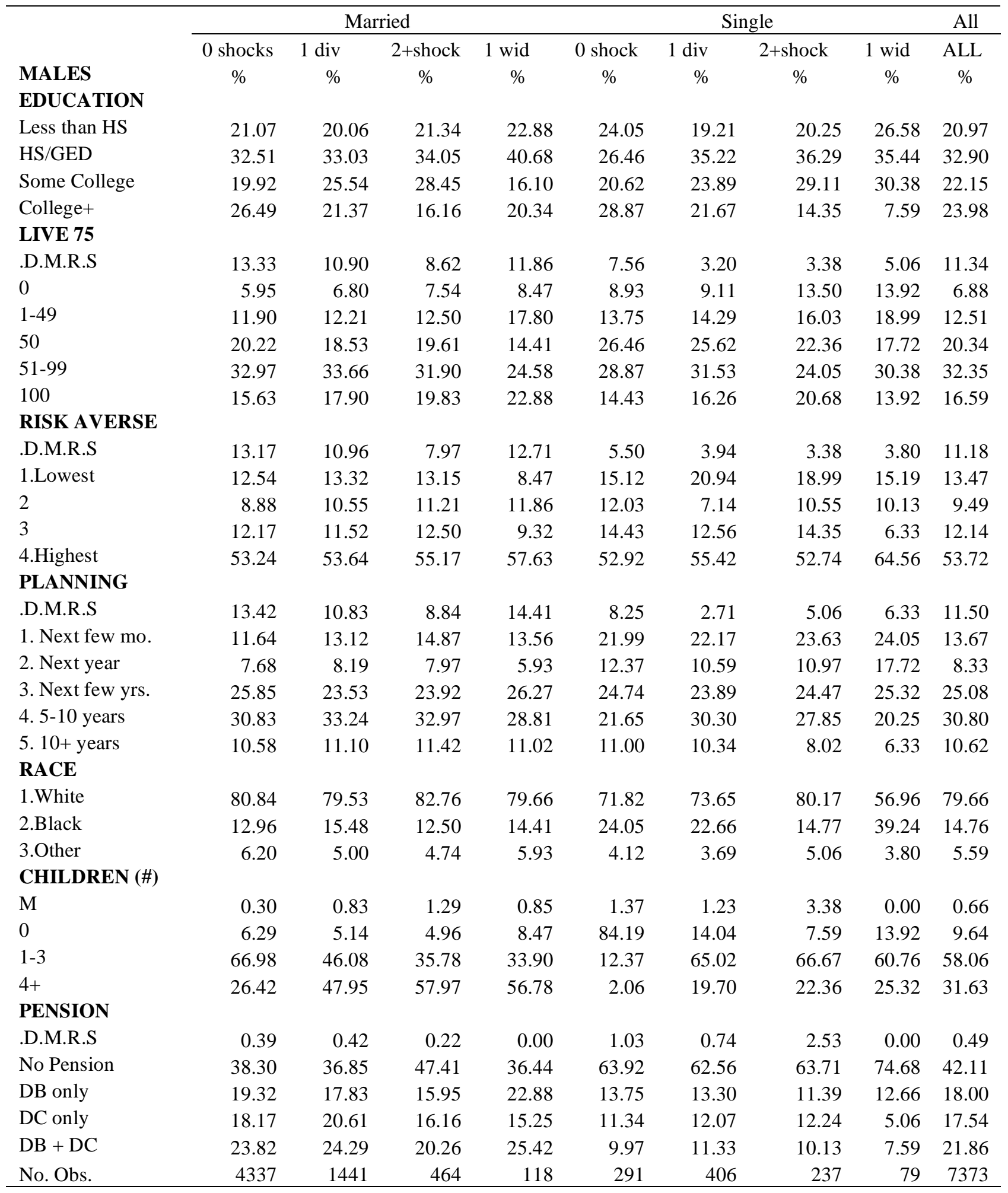


Appendix Table Cont.—Frequency of Model Covariates by Marital Categories-Females (percent distribution)

\begin{tabular}{|c|c|c|c|c|c|c|c|c|c|}
\hline \multirow{3}{*}{ FEMALE } & \multicolumn{4}{|c|}{ Married } & \multicolumn{4}{|c|}{ Single } & \multirow[t]{2}{*}{ All } \\
\hline & 0 shocks & $1 \mathrm{div}$ & $2+$ shock & 1 wid & 0 shock & $1 \mathrm{div}$ & $2+$ shock & 1 wid & \\
\hline & & & & & & & & & \\
\hline \multicolumn{10}{|l|}{ EDUCATION } \\
\hline Less than HS & 20.50 & 17.85 & 24.04 & 31.22 & 26.01 & 18.11 & 27.60 & 38.29 & 21.80 \\
\hline HS/GED & 39.21 & 39.24 & 35.96 & 41.46 & 32.08 & 35.48 & 35.73 & 32.59 & 38.00 \\
\hline Some College & 21.44 & 27.34 & 26.60 & 20.00 & 19.36 & 24.19 & 23.63 & 16.70 & 22.59 \\
\hline College+ & 18.85 & 15.57 & 13.40 & 7.32 & 22.54 & 22.21 & 13.04 & 12.42 & 17.61 \\
\hline \multicolumn{10}{|l|}{ LIVE 75} \\
\hline .D.M.R.S & 6.09 & 5.26 & 2.77 & 4.88 & 8.67 & 5.09 & 3.78 & 4.28 & 5.56 \\
\hline 0 & 4.84 & 4.64 & 7.66 & 6.34 & 5.78 & 6.82 & 9.07 & 5.70 & 5.46 \\
\hline $1-49$ & 10.51 & 11.28 & 11.70 & 10.73 & 10.40 & 10.67 & 11.34 & 13.24 & 10.89 \\
\hline 50 & 20.21 & 19.45 & 22.55 & 20.49 & 19.08 & 19.35 & 19.47 & 22.00 & 20.15 \\
\hline $51-99$ & 39.48 & 36.12 & 37.87 & 36.10 & 36.42 & 34.74 & 32.51 & 34.62 & 37.68 \\
\hline 100 & 18.87 & 23.25 & 17.45 & 21.46 & 19.65 & 23.33 & 23.82 & 20.16 & 20.26 \\
\hline \multicolumn{10}{|l|}{ RISK AVERSE } \\
\hline .D.M.R.S & 6.67 & 5.12 & 3.83 & 4.88 & 6.94 & 4.34 & 5.10 & 5.50 & 5.93 \\
\hline 1. Lowest & 9.93 & 11.21 & 14.26 & 9.27 & 12.14 & 12.53 & 12.67 & 12.42 & 10.90 \\
\hline 2 & 9.93 & 9.20 & 5.32 & 5.85 & 9.25 & 12.16 & 8.32 & 9.16 & 9.54 \\
\hline 3 & 12.57 & 14.39 & 16.60 & 10.24 & 10.40 & 12.28 & 11.53 & 8.55 & 12.63 \\
\hline 4. Highest & 60.90 & 60.07 & 60.00 & 69.76 & 61.27 & 58.68 & 62.38 & 64.36 & 61.01 \\
\hline \multicolumn{10}{|l|}{ PLANNING } \\
\hline .D.M.R.S & 6.35 & 5.26 & 3.83 & 5.85 & 7.23 & 4.34 & 3.78 & 5.91 & 5.75 \\
\hline 1. Next few mo. & 15.13 & 18.62 & 18.09 & 23.41 & 23.99 & 24.94 & 23.44 & 24.03 & 18.04 \\
\hline 2. Next year & 9.89 & 8.44 & 10.21 & 10.73 & 10.12 & 6.95 & 10.78 & 11.81 & 9.61 \\
\hline 3. Next few yrs. & 29.27 & 27.82 & 27.45 & 27.32 & 24.86 & 25.43 & 27.41 & 27.70 & 28.25 \\
\hline 4. $5-10$ years & 28.91 & 29.27 & 29.15 & 23.41 & 22.83 & 26.80 & 25.33 & 21.59 & 27.89 \\
\hline 5. $10+$ years & 10.46 & 10.59 & 11.28 & 9.27 & 10.98 & 11.54 & 9.26 & 8.96 & 10.46 \\
\hline \multicolumn{10}{|l|}{ RACE } \\
\hline 1.White & 80.39 & 80.55 & 86.81 & 77.56 & 49.71 & 64.64 & 69.57 & 59.06 & 76.55 \\
\hline 2.Black & 13.52 & 15.50 & 8.72 & 18.54 & 42.20 & 29.78 & 24.01 & 35.23 & 17.79 \\
\hline 3.Other & 6.09 & 3.94 & 4.47 & 3.90 & 8.09 & 5.58 & 6.43 & 5.70 & 5.67 \\
\hline \multicolumn{10}{|l|}{ CHILDREN (\#) } \\
\hline M & 0.28 & 0.55 & 0.43 & 1.46 & 0.58 & 0.50 & 1.13 & 0.61 & 0.45 \\
\hline 0 & 3.74 & 2.91 & 3.40 & 2.44 & 56.65 & 10.17 & 6.43 & 5.91 & 6.28 \\
\hline $1-3$ & 65.82 & 45.26 & 34.04 & 40.98 & 33.24 & 64.76 & 60.49 & 56.62 & 58.60 \\
\hline $4+$ & 30.16 & 51.28 & 62.13 & 55.12 & 9.54 & 24.57 & 31.95 & 36.86 & 34.67 \\
\hline \multicolumn{10}{|l|}{ PENSION } \\
\hline .D.M.R.S & 0.34 & 0.48 & 0.21 & 0.49 & 2.31 & 1.61 & 1.70 & 1.63 & 0.68 \\
\hline No Pension & 42.18 & 43.94 & 51.49 & 55.12 & 58.96 & 55.46 & 61.25 & 68.64 & 47.31 \\
\hline DB only & 18.36 & 18.27 & 14.89 & 12.68 & 15.61 & 17.37 & 12.29 & 11.61 & 17.19 \\
\hline DC only & 17.13 & 16.75 & 14.47 & 17.07 & 10.40 & 15.63 & 18.53 & 12.02 & 16.39 \\
\hline $\mathrm{DB}+\mathrm{DC}$ & 21.99 & 20.55 & 18.94 & 14.63 & 12.72 & 9.93 & 6.24 & 6.11 & 18.43 \\
\hline No. Obs. & 5289 & 1445 & 470 & 205 & 346 & 806 & 529 & 491 & 9581 \\
\hline
\end{tabular}

